\title{
SITE CHARACTERIZATION AND SEISMIC SITE RESPONSE STUDY OF THE SAHARY AREA, SOUTH EGYPT
}

\author{
Abdelnasser MOHAMED ${ }^{1) *}$, Conrad LINDHOLM ${ }^{2)}$ and Milad GIRGIS ${ }^{1)}$ \\ ${ }^{1)}$ National Research Institute of Astronomy and Geophysics (NRIAG), P. O. Box 152 Aswan, Egypt \\ ${ }^{2)}$ NORSAR, P.O. Box 53, NO-2027 Kjeller, Norway \\ *Corresponding author's e-mail: nassermhmd@yahoo.com
}

\begin{tabular}{l} 
ARTICLE INFO \\
\hline Article history: \\
Received 6 April 2015 \\
Accepted 23 June 2015 \\
Available online 27 August 2015 \\
\hline
\end{tabular}

\section{Keywords:}

Sahary area (Egypt)

Seismic refraction profiling

H/V Nakamura's technique

Site fundamental frequency

\begin{abstract}
The Sahary area is located about $1.5 \mathrm{~km}$ west of the Aswan High Dam. This is the nearest urban zone to the main active seismic zone (Kalabsha zone) in South Egypt. The main target of the present study is site characterization and the estimation of seismic site response by using shallow seismic refraction survey and the Nakamura technique ( $\mathrm{H} / \mathrm{V}$ spectral ratio). For this purpose, four shallow seismic refraction profiles and fifteen single station microtremor measurements were carried out distributed to cover the study area. The results showed that, the P-wave velocity of the surface layer ranges from 873 to $1341 \mathrm{~m} / \mathrm{s}$ and from 2164 to $2467 \mathrm{~m} / \mathrm{s}$ for the second (bed rock) layer. For the H/V spectral ratio technique it was noticed that most of the sites do not show a clear peak for natural fundamental frequency. All the sites exhibited many peaks that have been interpreted as being related to industrial noise sources due to the fact that the Sahary area has a lot of activities (turbines, generators, trucks, pumps...............etc).
\end{abstract}

\section{INTRODUCTION}

The Sahary dwelling area covers an area of about $1.25 \mathrm{~km}^{2}$ (Fig. 1). There are many industrial activities in and around the Sahary area including a lot of public work machines and human activities (e.g. turbines and pumps). Due to its location, very close to the active main seismic zone in South Egypt, it was chosen for the present study, especially considering the Nov. 07, 2010 earthquake $(M=4.6)$. The 2010 earthquake with epicentral distance around $2.5 \mathrm{~km} \mathrm{NE}$ of Sahary was strongly felt in the area, so it became important to conduct a study of earthquake hazard and risk mitigation for the Sahary area. The present study aims to characterize the foundation rocks and to estimate the seismic site response at Sahary area by applying two techniques (The shallow seismic refraction and the $\mathrm{H} / \mathrm{V}$ spectral ratio). These two techniques have been applied at different sites in Aswan area e.g. Mohamed (2004, 2010), Fat-Helbary et al. (2006), Mohamed and Fat-Helbary (2010) and Mohamed et al. (2013) but in the present study we apply these techniques for the first time in the Sahary area.

\section{GEOLOGICAL AND STRUCTURAL SETTING OF THE AREA}

Several investigators have previously studied the geology of the area e.g. Said (1962), Issawi (1968, 1981), and WCC (1985). The geology of the Aswan area is controlled by regional basement uplift and faulting. In this area, the Nile follows the contact between the exposed basement granite of the Eastern
Desert to the east, and the sedimentary cover of the Nubian sandstone to the west. The Nubian sandstone Formation represents the oldest sedimentary deposits that occur over large areas in southern Egypt and northern Sudan. The Nubian sandstone plain extends from the western lake shoreline of the Lake Nasser to the Sin El Kaddab scarp (in its northern sectors) and extends until it reaches the basement complex and volcanic rocks exposure to the west (in its southern sector). The Nubian sandstone is exposed of nearly horizontal sediments, relatively undeformed and gently dipping westward. Structurally, the faults in this area are part of the Western Desert fault system. According to WCC (1985), the Western Desert fault system consists of a set of east-west (EW) faults that exhibit right lateral slip displacement, and a set of north-south (NS) faults that exhibit left lateral slip displacement. The EW trending fault system includes the Kalabsha fault and the Seiyal fault, while the NS trending fault system consists of the Gabel el-Barqa fault, the Kurkur fault, the Khor el-Ramla fault, and the Abu Dirwa fault (Fig. 2).

\section{SEISMICITY IN AND AROUND THE SAHARY AREA}

The main shock of Nov. 14, $1981\left(M_{b} 5.6\right)$ in the Kalabsha area, around $60 \mathrm{~km}$ southwest of Aswan was the largest earthquake recorded in this region. The seismic activity in the Aswan area mainly occurred near the epicenter of that earthquake in and around the Kalabsha seismic zone. In terms of depth characteristics, the earthquakes can be divided into 


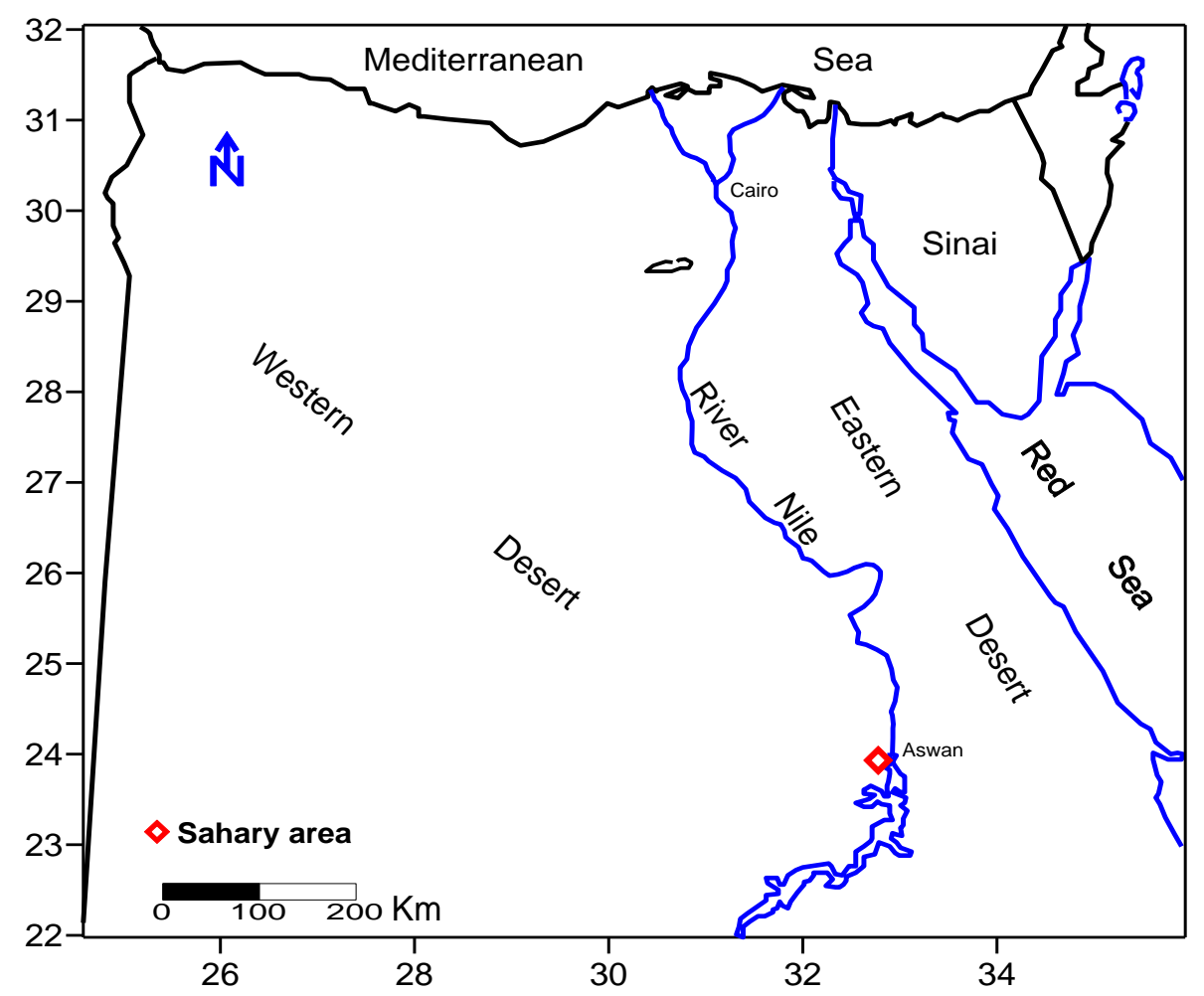

Fig. 1 Location map of the study area, the Sahary area is indicated with the red diamond.

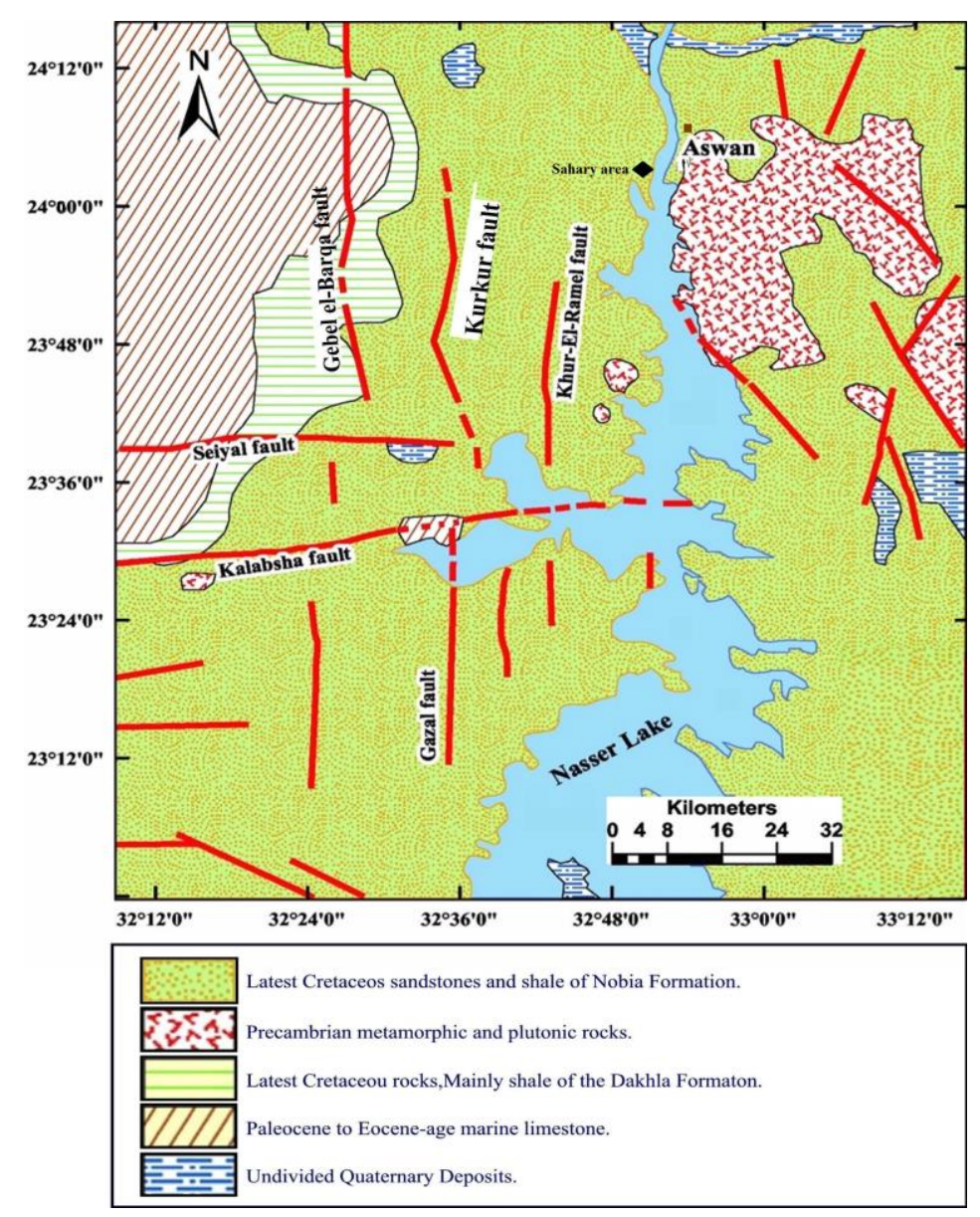

Fig. 2 Geological and structural map of Aswan area. 

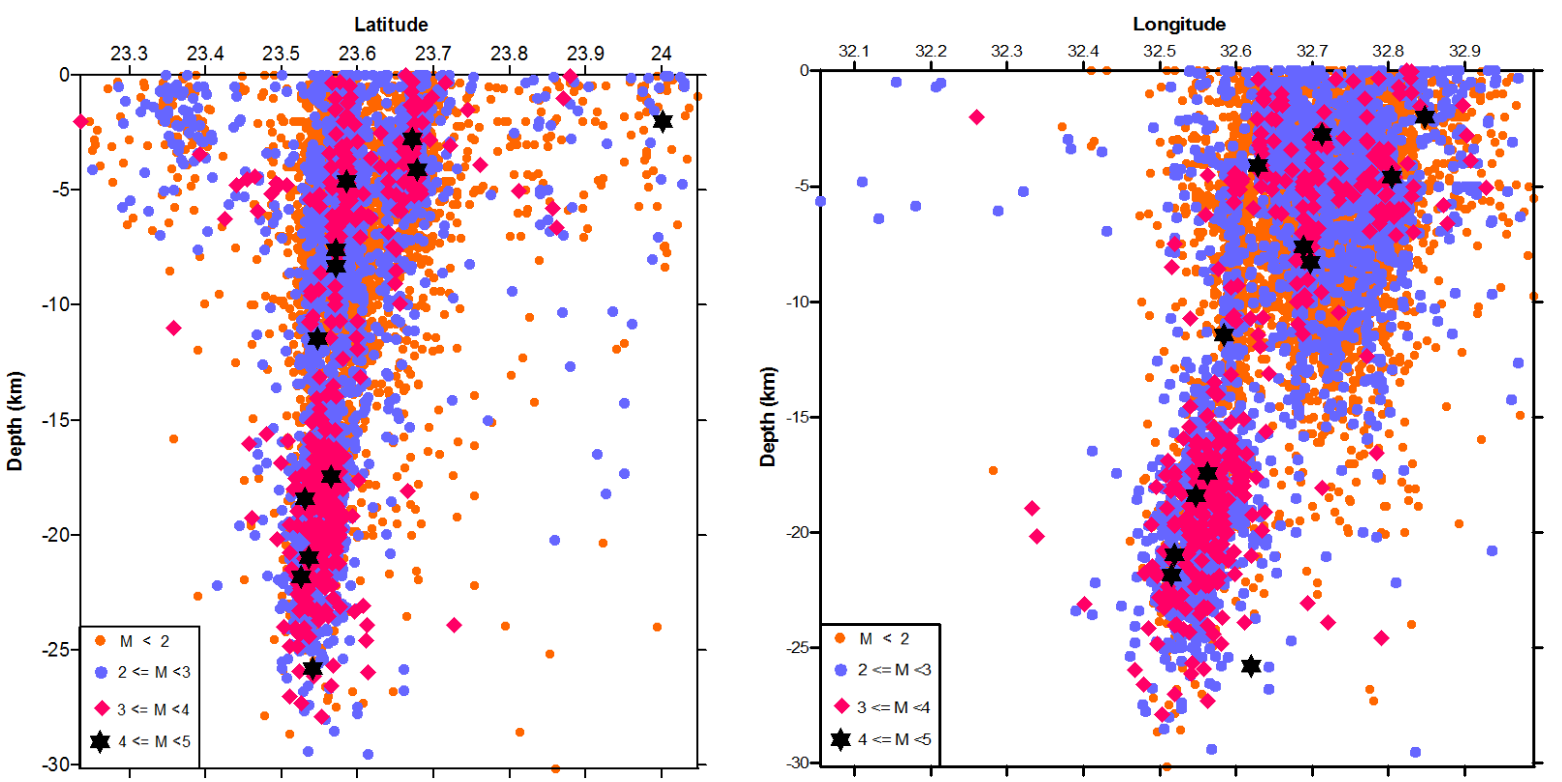

Fig. 3 Vertical cross sections showing the distribution of earthquakes depth Norh-South (Left) and East-West (Right) directions respectively at Aswan area during the period from 1982-2014.

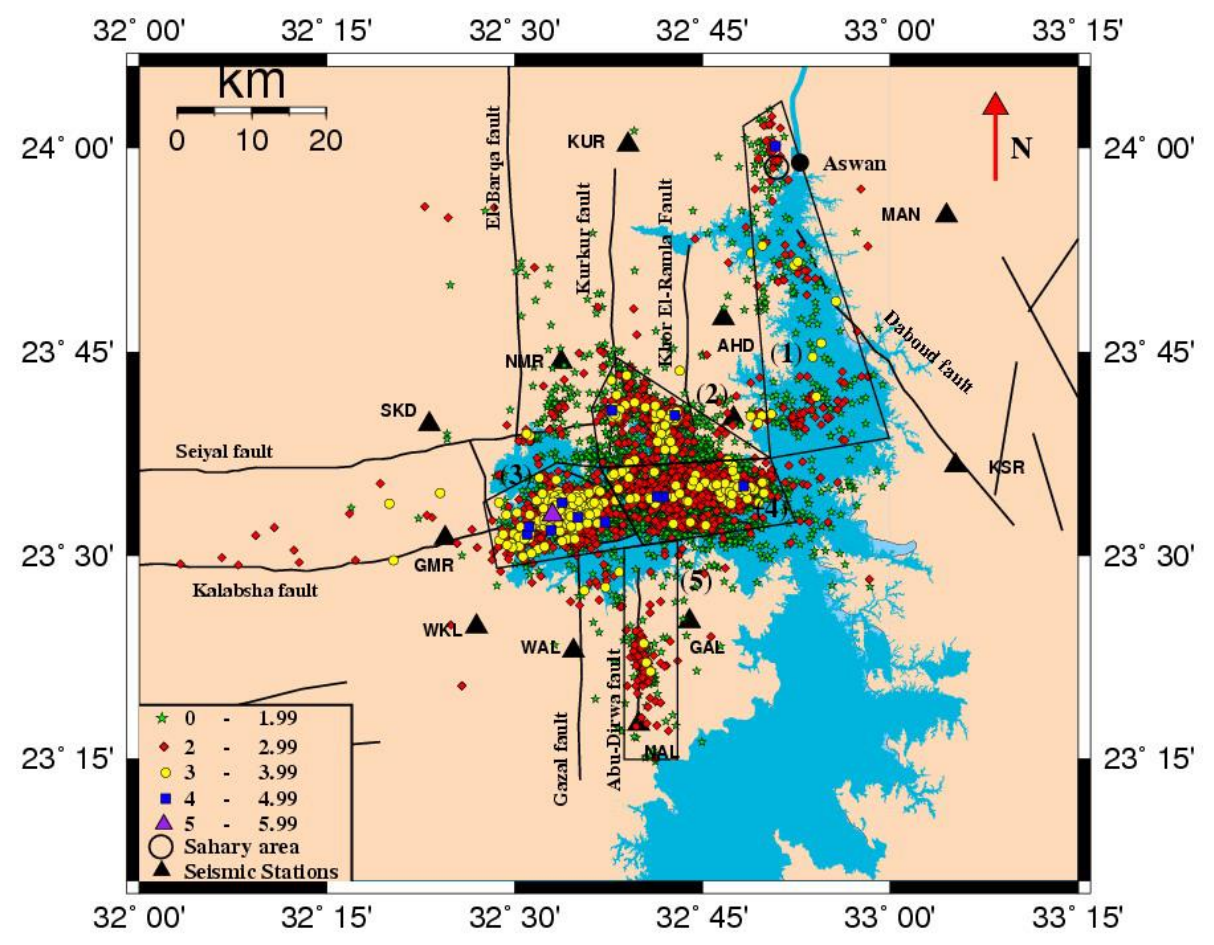

Fig. 4 Seismic activity in Aswan area from 1982-2014. Five main cluster zones, (1) Old Stream, (2) Khor El-Ramla, (3) Gebel Marawa, (4) East of Gebel Marawa and (5) Abu Dirwa zone are indicated by numbers.

two major groups, shallow earthquakes with depth ranges from 0 to about $13 \mathrm{~km}$ and deep earthquakes with depths greater than $13 \mathrm{~km}$ down to $30 \mathrm{~km}$ (Fig. 3). Many investigations on the characteristics of the seismic activity in Aswan area have been carried out (Kebeasy et al., 1987; Fat-Helbary, 1989; Simpson et al., 1989; Kebeasy and Gharib, 1991; Haggag, 1997; Hassib, 1997 and Dahy, 2012) and others. The spatial distribution of the earthquakes in Aswan area during the period from 1982 to 2014 is shown in Figure 4. This distribution of the earthquakes shows that the seismicity is concentrated in five main cluster zones, (1) Old Stream, (2) Khor El-Ramla, (3) Gebel Marawa, (4) East of Gebel Marawa and (5) Abu Dirwa zone. 


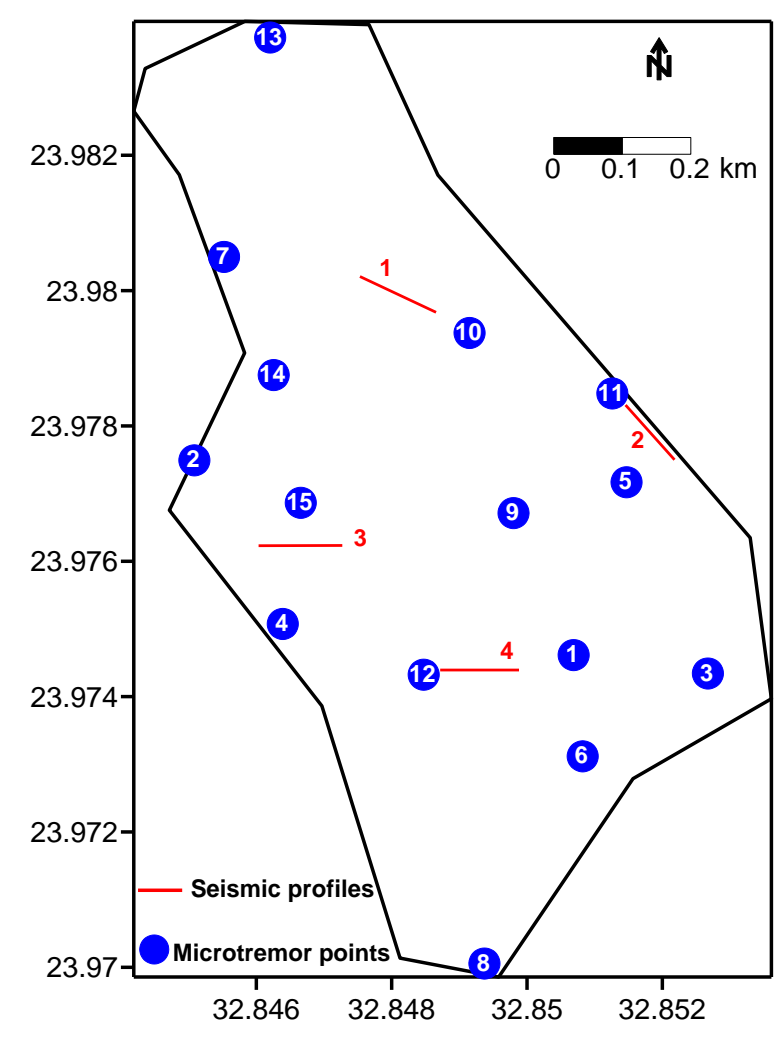

Fig. 5 Location of seismic profiles and microtremors recording points with the Sahary area.

\section{SHALLOW SEISMIC REFRACTION SURVEY}

The shallow seismic refraction technique is considered as one of the most effective geophysical methods, which can be applied in the field of engineering seismology i.e. for tunnels, dam sites, landslides, quarries, roads, reclaim of lands, caves and cavities. The main targets of the shallow seismic refraction method are the determination of the depth to the bedrock, the depth to the ground water, lithology type, the lateral and vertical changes in lithology, and investigate structural features such as, micro fault and cracks. The technique for generating $\mathrm{P}$-waves is to hit the ground vertically. The created seismic waves propagate through the subsurface layers, and the direct and refracted waves are recorded by sensitive geophones.

\section{DATA ACQUISITION, PROCESSING AND INTERPRETATION}

In this study, the shallow seismic refraction survey was used to determine the subsurface layering and structures within the Sahary area, Aswan, South Egypt. Four seismic refraction profiles were conducted (Fig. 5) with $115 \mathrm{~m}$ length by using 24 geophones with $5 \mathrm{~m}$ geophone intervals. Along each profile, three shots (sledgehammer hits with $8 \mathrm{~kg}$ weight) were conducted, at distances of $5 \mathrm{~m}$ away from both ends (normal and reverse shooting), and at the mid-point between geophones 12 and 13. The seismic signals are recorded in the present study using the Geometrics seismograph (Strata Visor NZ 48 channels). The travel time-distance curves are constructed based on the refracted waves from the subsurface layering interface. From the seismic sections obtained from each shot, the P-waves first arrivals were picked. The picked data were analyzed using SeisImager/2D software (OYO Corporation, 2004). From the analyzed data, the P-wave velocities for each layer were calculated and corresponding 2-D geometrical model for each site was established.

From the results of the seismic refraction survey, it was noticed that there are two layers in the area with depth ranges from 25 to $30 \mathrm{~m}$. as shows in the depth velocity model in Figure (6). The upper layer is mainly composed of claystone intercalated with grained sandstone found in profiles No. 1, 2 and 3, while in profile No. 4 it is mainly composed of a weathered layer including sand, gravel and some fragments of friable sandstone. The second layer (bed rock) is mainly composed of Nubian sandstone. The P-wave velocities of the surface layer are 1318, 1063, 1341 and $873 \mathrm{~m} / \mathrm{s}$ for profile number No. 1, 2, 3 and 4 respectively. The thickness of this layer ranges from 1 to $10 \mathrm{~m}$ with a mean value of about $7.5,7$, 2 and $6.5 \mathrm{~m}$ at profiles $1,2,3$, and 4 respectively.

\section{H/V SPECTRAL RATIO (THE NAKAMURA TECHNIQUE)}

Microtremors are ambient vibrations of the ground excited by natural sources (continental, oceanic waves, wind, river flows and atmospheric pressure changes) and/or distant artificial (humans) disturbances, such as traffic, industrial machinery or railways (Field et al., 1990). Many authors used the horizontal to vertical $(\mathrm{H} / \mathrm{V})$ spectral ratio technique (Nakamura, 1989) on ambient vibrations to determine the resonance frequency $\left(\mathrm{f}_{0}\right)$ and sometimes to assess the associated amplification of ground motion $\left(\mathrm{A}_{0}\right)$ in urban environments (Duval et al., 2001; Lebrun et al., 2001; Panou et al., 2005). This technique has become very popular to obtain a quick microzonation map especially in urban area due to its ease of operation and non destructive nature. Although not foolproof the technique has already proved to be one of the most inexpensive, robust and convenient techniques to relatively reliably estimate fundamental frequencies of soft deposits. Extensive use of this method allows a detailed mapping of the resonance frequency within urban areas (Faeh et al., 2001).

\section{DATA ACQUISITION, PROCESSING AND INTERPRETATION}

Fifteen microtremors measurements were carried out in the study area (Fig. 5) using three-component seismometer (Trillium Compact 120s) and a Taurus Portable recorder. Continuous ambient vibration signals were recorded for durations from 60 to 
1

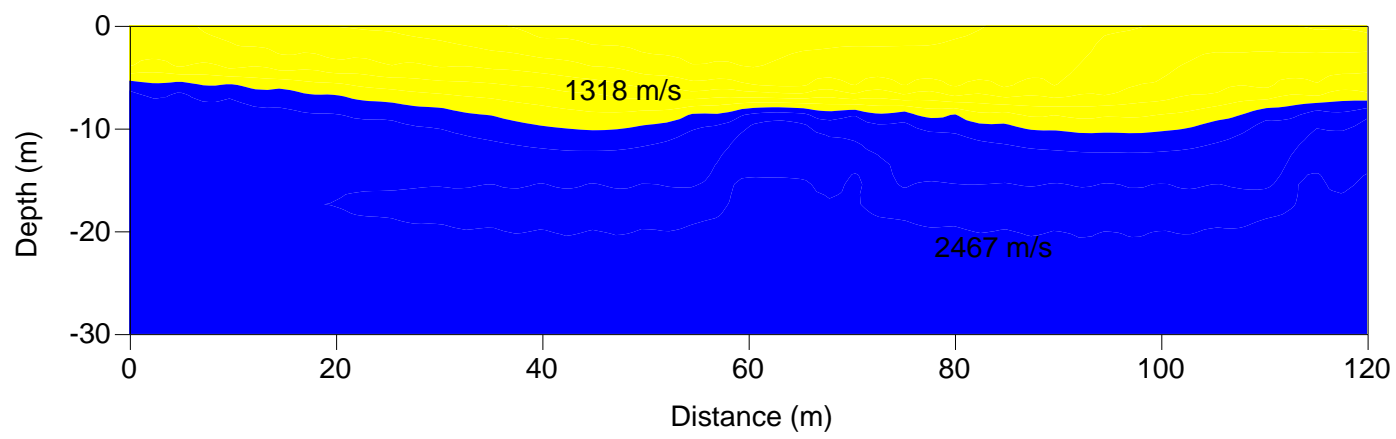

2

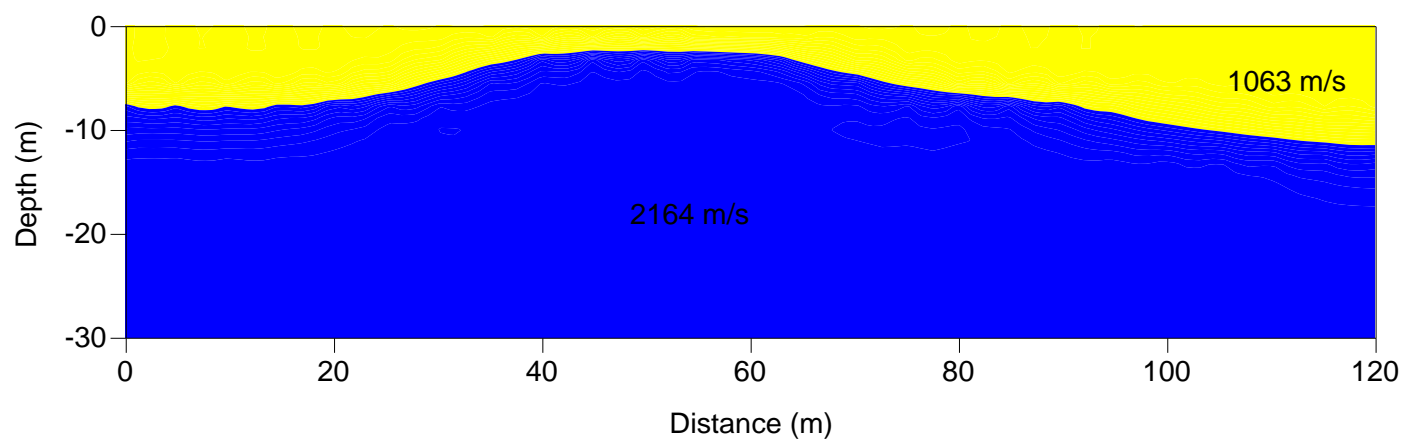

3

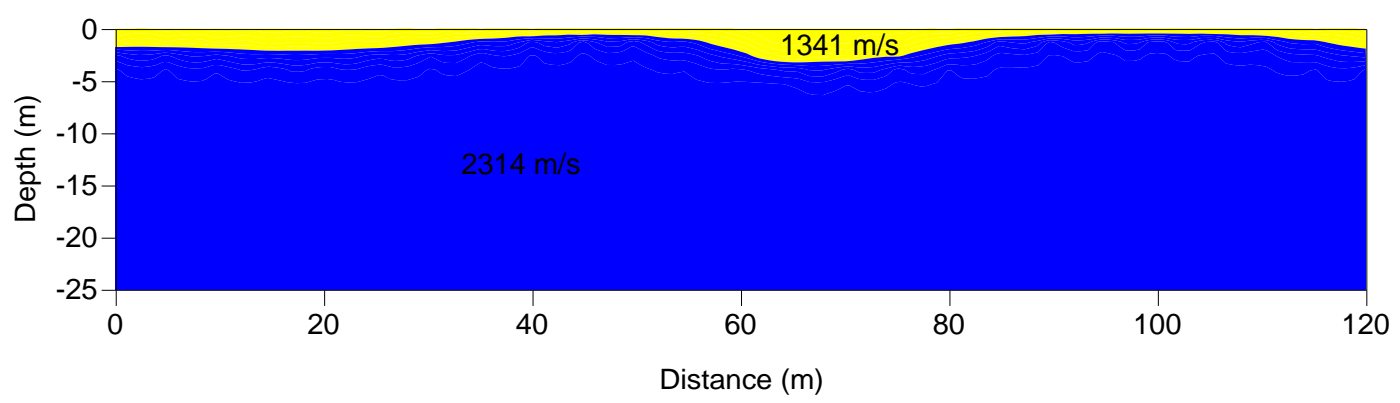

4

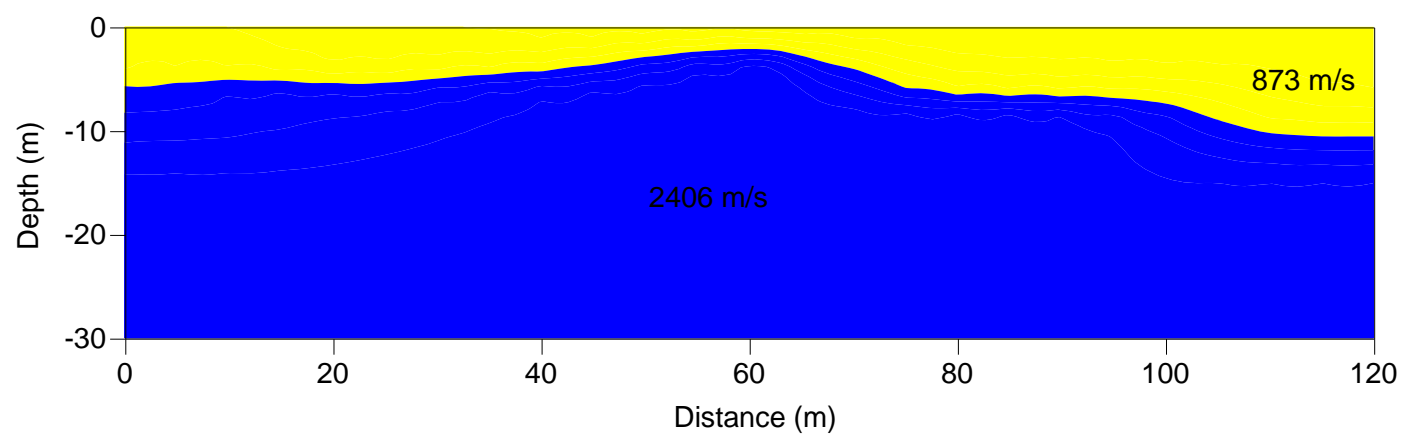

Fig. 6 2-D underground velocity model profiles for the profiles center points shown in Figure 5. From top to bottom the 1,2, 3 and 4 profiles respectively.

87 minutes at each site with a sample rate $100 \mathrm{sps}$ for all sites. The measurements were done during daytime and the precautions of Duval (1994); Nakamura (1996); and the SESAME project guidelines have been applied.

The recorded data were analyzed using the Geopsy software (http://www.geopsy.org) and focused on the frequency range between 0.5 and $20 \mathrm{~Hz}$. The recorded signal for each site was subdivided into time windows with 60 second duration and at least 10 windows were used. Cosine tapering of the time series with $5 \%$, a bandwidth coefficient value of 40 and smoothing of the Fourier amplitude spectra by the algorithm of KonnoOhmachi (1998) were used in the current data processing. At the final step, the two horizontal components were merged together using a geometrical mean option:

$H=\left(\left|x_{f} y_{f}\right|\right)^{0.5}$ 
Table 1 Soil profile type classification for seismic amplification (BSSC, 2003).

\begin{tabular}{ccc}
\hline $\begin{array}{c}\text { Soil type } \\
\text { NEHRP }\end{array}$ & General description & $\begin{array}{c}\text { Average shear wave } \\
\text { velocity to 30 } \mathbf{~}(\mathbf{m} / \mathbf{s})\end{array}$ \\
\hline $\mathrm{A}$ & Hard Rock & $>1500$ \\
\hline $\mathrm{B}$ & Rock & $760<\mathrm{Vs} \leq 1500$ \\
\hline $\mathrm{C}$ & Very dense soil and soft rock & $360<\mathrm{Vs} \leq 760$ \\
\hline $\mathrm{D}$ & tiff soil $15 \leq \mathrm{N} \leq 50$ or $50 \mathrm{kPa} \leq \mathrm{Su} \leq 100 \mathrm{kPa}$ & $180 \leq \mathrm{Vs} \leq 360$ \\
\hline & Soil or any profile with more than $3 \mathrm{~m}$ of soft clay defiled as \\
$\mathrm{E}$ & soil with PI $>20, \mathrm{w} \geq 40 \%$, and $\mathrm{Su}<25 \mathrm{kPa}$. & $\leq 180$ \\
\hline $\mathrm{F}$ & Soils requiring site-specific evaluations \\
\hline
\end{tabular}

Where: $\mathrm{H}$ is the horizontal component computed by geometrical mean, $x_{f}$ is the modulus of spectra of N$\mathrm{S}$ component, and $y_{f}$ is the modulus of spectra of E W component. Then, the H/V spectral ratio for each individual time window was computed by dividing the spectra of the merged horizontal components to the vertical component. Finally, the spectral ratios relative to all the time windows were considered when averaged, and the main $\mathrm{H} / \mathrm{V}$ spectral ratio (HVSR) curve was computed with the standard deviation at each frequency of interest. Detailed examinations were made on $\mathrm{H} / \mathrm{V}$ curves before the extraction of information to ensure the reliability of the $\mathrm{H} / \mathrm{V}$ peaks. Reliability implies stability; this means that the actual $\mathrm{H} / \mathrm{V}$ curve obtained with the selected recordings should be representative of $\mathrm{H} / \mathrm{V}$ curves that could be obtained with other ambient vibration recordings and/or with other physically reasonable window selection. The clarity and reliability of the HVSR peaks were verified for all sites according to SESAME guidelines (D23.12, 2004). Also, particular attention was devoted to identify sharp peaks of industrial sources. A very effective check is to apply the random decrement technique (Dunand et al., 2002) to the ambient vibration recordings in order to derive the "impulse response" around the frequency of interest. If the corresponding damping $(\mathrm{Z})$ is very low (below 1\%), an anthropogenic origin may be assumed almost certainly, and the frequency should not be considered in any interpretation. In this study, peaks with an industrial origin, related to some kind of machinery (relative near field noise from turbines, generators, etc.) were detected at all sites. According to the SESAME recommendation these peaks were not considered in any interpretation. Representative examples of the results at the study area are shown in Figures (7-10), point 13 for North, point 8 for South, point 11 for East and point 2 for West directions respectively.

\section{DISCUSSION AND CONCLUSIONS}

The seismic refraction survey technique and the Nakamura technique were applied at the Sahary area to characterize the subsurface structure and to determine the resonance frequency of the soils underlying the Sahary area. The results of the seismic refraction survey indicated that the geology of Sahary area is homogeneous and consists of two layers, the first layer is a weathered surface layer mainly composed of claystone intercalated with grained sandstone while the second layer (bedrock) is Nubian Sandstone. In conclusion, the sedimentary cover in the area is relatively thin (few meters) and the bedrock formations (Nubian Sandstone) reach the surface at some locations, so there is a good agreement between the results of the shallow seismic refraction survey and the surface/subsurface geology of the study area. Classifications were made according to the National Earthquake Hazards Reduction Program (NEHRP), BSSC (2003) which is anchored to the average shearwave velocity in the upper 30 meters (Table 1).

In the study area, we did not record shear waves directly, so Vs was computed indirectly from the $\mathrm{P}$-wave velocities using $\mathrm{Vp} / \mathrm{Vs}$ ratio equal to 1.7 derived from Mohamed (2004) of the upper $30 \mathrm{~m}$ and according to that the study area is classified as soil type B. The fifteen microtremors measurements that carried out in the study area showed that there are peaks of ambient noise of industrial origin in the frequency range $(0.5-6.0 \mathrm{~Hz})$ affecting most of the measured sites. These peaks are attributed to the effect of the main electric power facility and local machinery (generators, trucks,..........etc). According to SESAME (2004), the artificial ambient sources (such as heavy trucks/public works machines at close and intermediate distances (within a few hundred meters)) shall be avoided. We tried to avoid these noise sources, but our data clearly demonstrate that we were only partly successful in this respect. It seems that we must conclude that under the current logistical conditions the $\mathrm{H} / \mathrm{V}$ spectral ratio technique may not be a suitable technique for determining the fundamental frequency in the Sahary area. This study recommends performing additional measurements if possible with long duration recording time during night time and/or under quiet weather conditions. Also, the use of Multi-channel Analysis of Surface Waves (MASW) can be useful to calculate the $\mathrm{V}_{\mathrm{s} 30}$ more directly for the upper 30 meter and from the MASW results there 
will be a possibility to independently determine the fundamental frequency naturally depending on the thickness of the sediments in the study area.

\section{ACKNOWLEDGMENT}

The authors acknowledge the Research Council of Norway for support this study under grant 227301/F11. We appreciate the Aswan Earthquake Research Center (NRIAG) for providing the instruments and the facilities used in the study. Also grateful to Dr. Mostafa Toni for helpful discussions and comments.

\section{REFERENCES}

Awad, H. and Kwiatek, G.: 2005, Focal mechanism of earthquakes from the June 1987 swarm in Aswan, Egypt, calculated by the moment tensor inversion. Acta Geophysica Polonica, 53, No. 3, 275-291.

Dahy, S.A.: 2012, A study on shallow and deep focus earthquakes and relationship to the water level in the western side of the Aswan High Dam Lake, Egypt. Research Journal of Earth Sciences, 4, No. 2, 63-68.

Dunand, F., Bard, P.-Y., Chatelin, J.L., Guéguen, Ph., Vassail, T. and Farsi, M.N.: 2002, Damping and frequency from randomec method applied to in-situ measurements of ambient vibrations: Evidence for effective soil structure interaction. 12 $2^{\text {th }}$ European Conference on Earthquake Engineering, London. Paper \# 869.

Duval, A. M.: 1994, Determination de la response d'un site aux seismes a aide du bruit de fond: Evaluation expermentale (These de Doctorat). Paris VI, pp. 265, (in French).

Duval, A. M., Vidal, S., Méneroud, J.-P., Singer, A., De Santis, F., Ramos, C., Romero, G., Rodriguez, R., Pernia, A., Reyes, N. and Griman, C.: 2001, Caracas, Venezuela, site effect determination with microtremors. Pure Appl. Geophys., 158, 2513-2523. DOI: 10.1007/PL00001183

Faeh, D., Kind, F. and Giardini, D.: 2001: A theoretical investigation of average $\mathrm{H} / \mathrm{V}$ ratios. Geophys. J. Int., $145,535-549$.

DOI: 10.1046/j.0956-540x.2001.01406.x

Fat-Helbary, R.: 1989, A study of the local earthquake magnitude determination recorded by Aswan Seismic Network. Master Thesis, Assiute University, Sohag Faculty, Egypt.

Fat-Helbary, R., EL Faragawy, K. and Abdel-Motaal, A.: 2006, Engineering seismological studies on the proposed location of Aswan New City, Egypt. Acta Geodaetica et Geophysica Hungarica, 41, No. 2, 211225. DOI: 10.1556/AGeod.41.2006.2.6

Field, E. H., Hough, S. E. and Jacob, K. H.: 1990, Using microtremors to assess potential earthquake site response: a case study in flushing meadows, New York City. Bull. Seism. Soc. Am., 80, No. 6A, 14561480.

Haggag, H.: 1997, A study about the characteristics of the seismic activity at Kalabsha area and Aswan reservoir, Aswan. Ph. D. Thesis, South Valley University.

Hassib, G.: 1997, A study on the earthquake mechanics around High Dam Lake, Aswan, Egypt. Ph. D. Thesis, Faculty of Science, South Valley Univ., Sohag, Egypt, $14,73-82$.
Issawi, B.: 1968, The geology of Kurkur-Dungul area, Egypt. Geological Survey of Egypt, Cairo, 46, 102.

Issawi, B.: 1981, Geology of the southwestern Desert of Egypt. Annals of the Geological Survey of Egypt, V (XI), 57-66.

Kebeasy, R., Maamoun, M., Ibrahim, E., Megahed, A., Simpson, D. and Leith, W.: 1987, Earthquake studies as Aswan reservoir. J. Geodyn., 7, No. 3-4, 173-193. DOI: 10.1016/0264-3707(87)90003-2

Kebeasy, R. and Gharib, A.: 1991, Active fault and water loading are important factors in triggering earthquake activity around Aswan Lake. J. Geodyn., 14, 73-85. DOI: 10.1016/0264-3707(91)90010-C

Konno, K. and Ohmachi, T.: 1998, Ground-motion characteristics estimated from spectral ratio between horizontal and vertical components of microtremor. Bull Seism. Soc. Am., 88, No. 1, 228-241.

Lebrun, B., Hatzfeld, D. and Bard, P.-Y.: 2001, A site effect study in urban area: experimental results in Grenoble (France). Pure Appl. Geophys., 158, 2543-2557. DOI: 10.1007/978-3-0348-8177-7-16

Mohamed, A.: 2004, Engineering seismological studies on the proposed location of Aswan New City". M.Sc Thesis, Aswan Faculty of Science, South Valley University, Egypt.

Mohamed, A.: 2010, Engineering Seismology studies for Land-use planning at the proposed Tushka New City site, South Egypt". PhD Thesis, Aswan Faculty of Science, South Valley University, Egypt.

Mohamed, A. and Fat-Helbary, R.: 2010, Microtremors measurements for site effect investigation at Aswan New City, Egypt. Proceedings of the $14^{\text {th }}$ European Conference of Earthquake Engineering (14ECEE), Macedonia, 30 August-03 September, 2010.

Mohamed, A., Fat-Helbary, R., Basheer, A. and Dojcinovski, D.: 2013, Using ambient vibrations for site characterization at the new Aswan University site, Southern Egypt. SE50EEE International Conference on Earthquake Engineering, Macedonia, 29-31 May, 2013.

Nakamura, Y.: 1989, A method for dynamic characteristics estimation of subsurface using microtremor on the ground surface. Quaterly Report, Railway Tech. Res. Inst., 30-1, 25-30.

Nakamura, Y.: 1996, Real-time information systems for seismic hazard mitigation UrEDAS, HERAS and PIC. Quaterly Report, Railway Tech. Res. Inst. 37, 112127.

NEHRP: 2003, Recommended provisions for seismic regulations for New Buildings and Other Structures. Building Seismic Safety Council (BSSC) for the Federal Emergency Management Agency (FEMA 450). Washington, Part 1: Provisions.

OYO Corporation: 2004, Annual report, www.oyo.co.jp.

Panou, A., Theodulidis, N., Hatzidimitriou, P., Savvaidis, A. and Papazachos, C.: 2005, Reliability of ambient noise horizontal-to-vertical spectral ratio in urban environments: the case of Thessaloniki city (northern Greece). Pure Appl. Geophys., 162, No. 5, 891-912. DOI: $10.1007 / \mathrm{s} 00024-004-2647-6$

Said, R.: 1962, The geology of Egypt. Amsterdam, New York, Elsevier Pub. Comp., 377 pp.

SESAME: 2004, Site effects assessment using ambient excitations: Guidelines for the implementation of the $\mathrm{H} / \mathrm{V}$ spectral ratio technique on ambient vibrations measurements, processing and interpretation. 
European research project, WP12 - Deliverable D23.12.

Simpson, D., Gharib, A. and Kebeasy, R.: 1989, Induced seismicity and change in water level at Aswan reservoir. Gerlands Beitraege zur Geophysik, Special Issue on Induced Seismicity.

WCC (Woodward-Clyed Consultants): 1985, Earthquake activity and dam stability evaluation for the Aswan High Dam, Egypt. High and Aswan Dams Authority, Ministry of Irrigation, five volumes. 

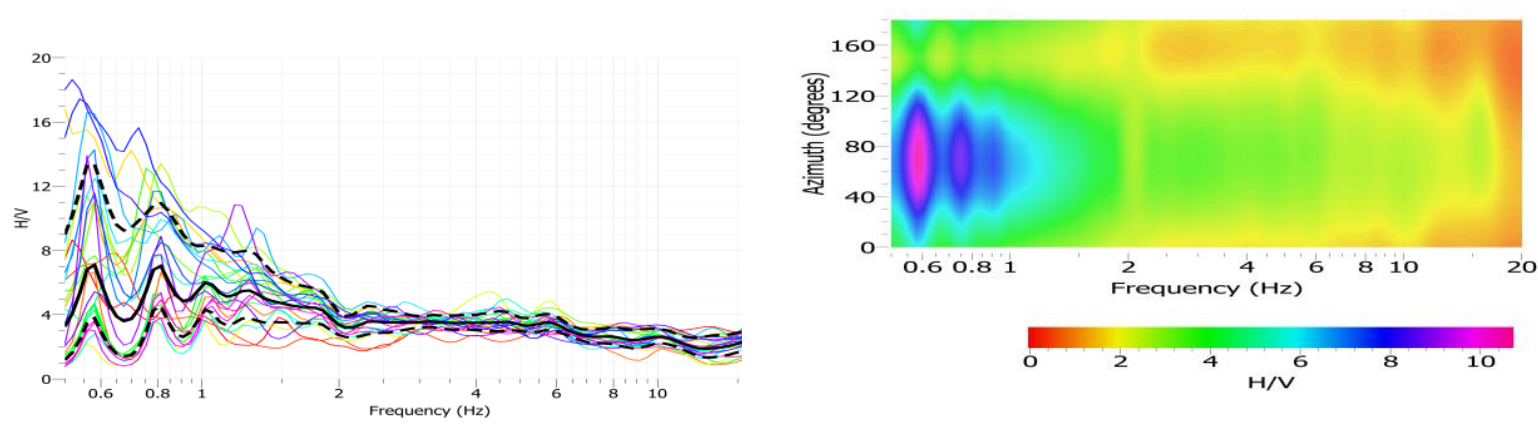

1

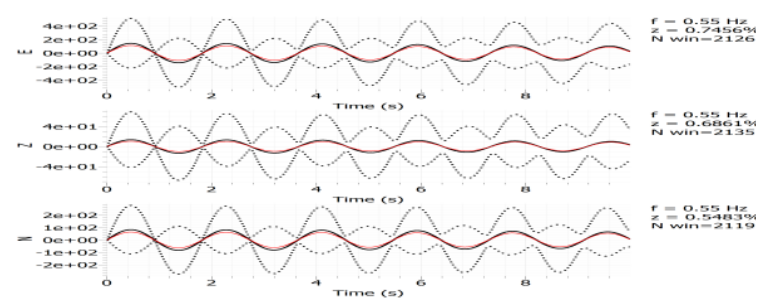

3

2

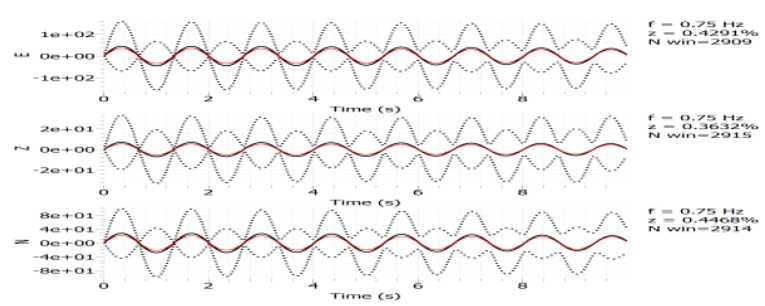

4

Fig. 7 Panel 1 represents the H/V spectral ratio curve; panel 2 shows the H/V rotation with azimuth degrees and panels 3 and 4 illustrate the damping test for the peak amplitude at frequencies $0.56 \mathrm{~Hz}$ and $0.75 \mathrm{~Hz}$ respectively.
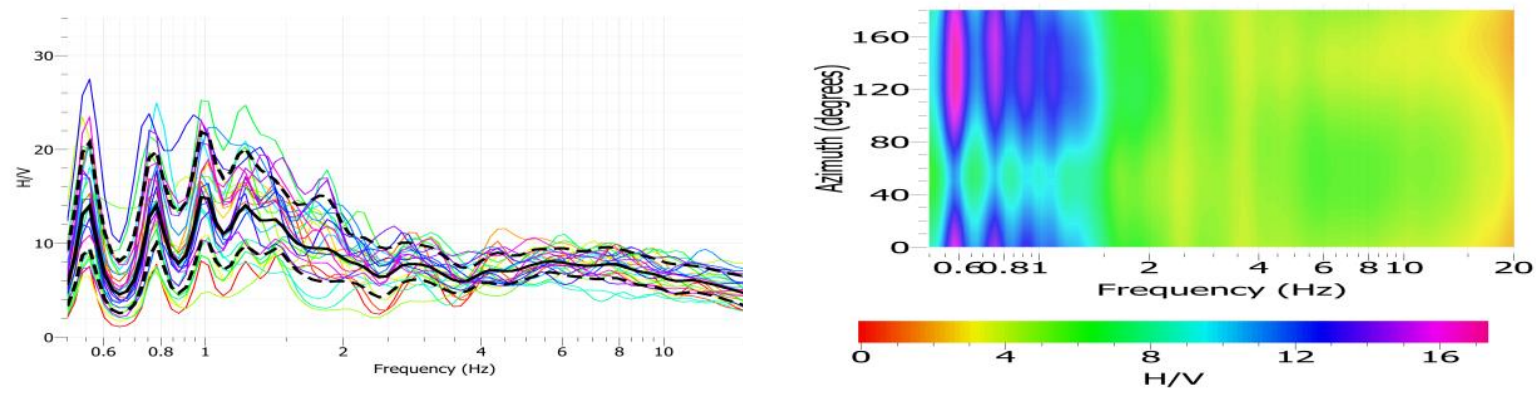

1

2

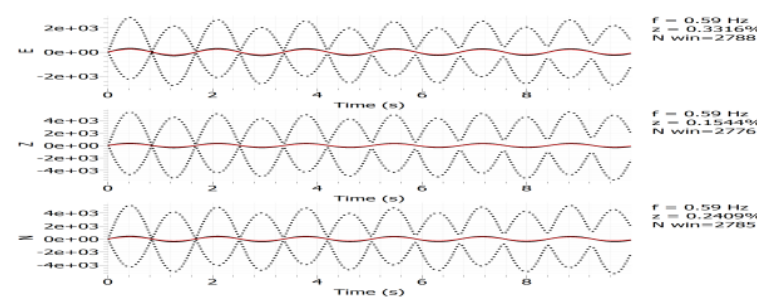

$\underset{\substack{10+03 \\-10+00}}{20+0)}$

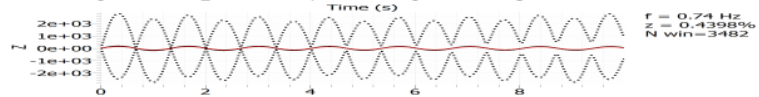
$\substack{20+03 \\=0+03 \\ 0+00 \\-20+03 \\-20+03}$
0 3

4
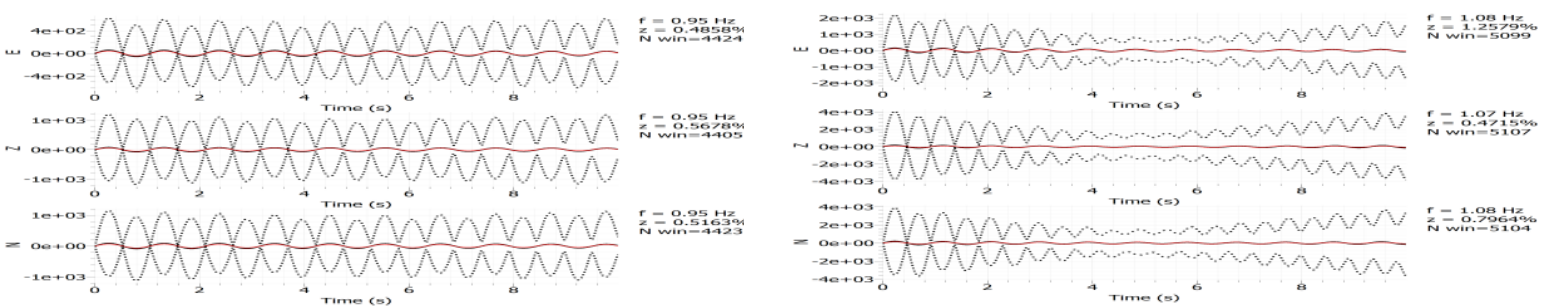

Fig. 8 Panel 1 represents the H/V spectral ratio curve; panel 2 shows the H/V rotation with azimuth degrees and panels 3 , 4,5 , and 6 illustrate the damping test for the peak amplitude at frequencies $0.56,0.750 .95$, and $1.08 \mathrm{~Hz}$ respectively. 


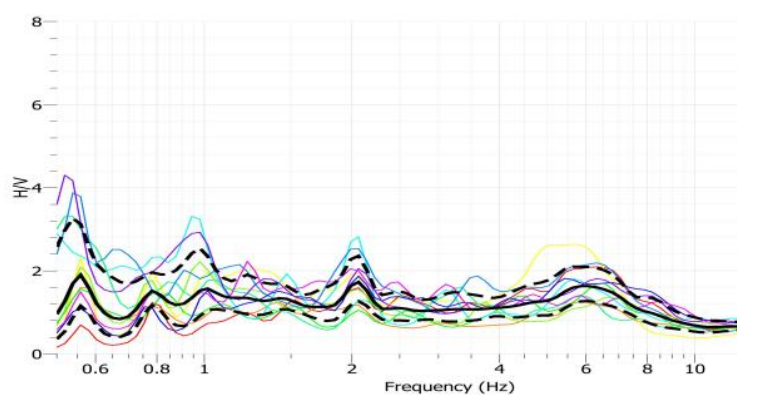

1

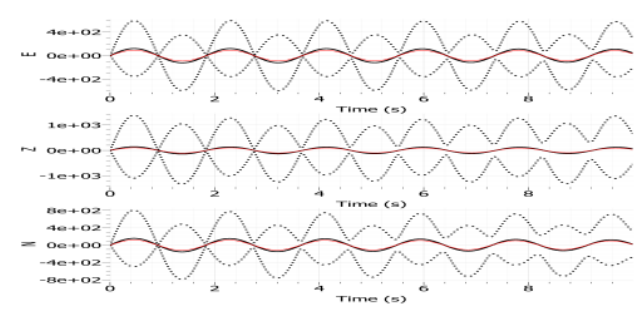

Nons

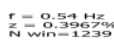

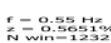

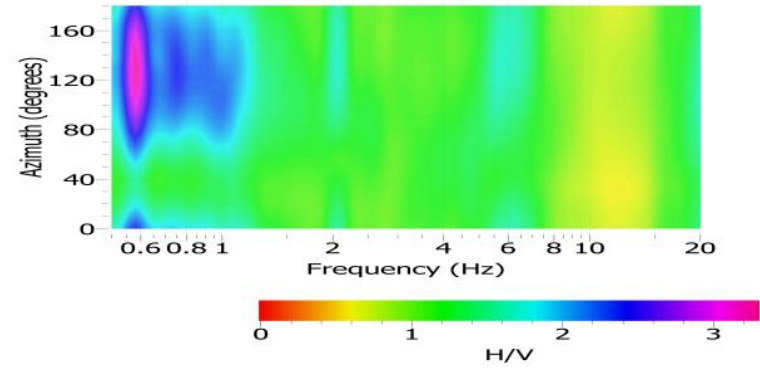

2

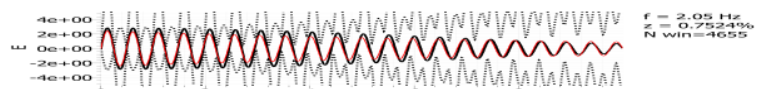

cecosh

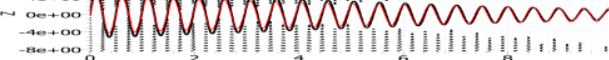

-

3

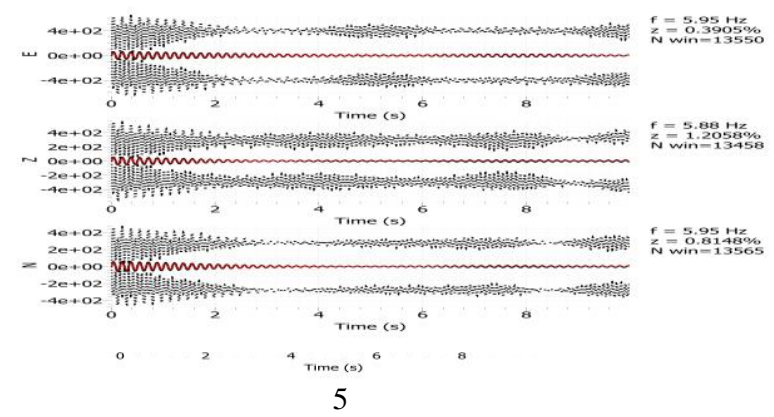

Fig. 9 Panel 1 represents the H/V spectral ratio curve; panel 2 shows the H/V rotation with azimuth degrees and panels 3 , 4, and 5 illustrate the damping test for the peak amplitude at frequencies $0.56,2.05$ and $5.95 \mathrm{~Hz}$ respectively.

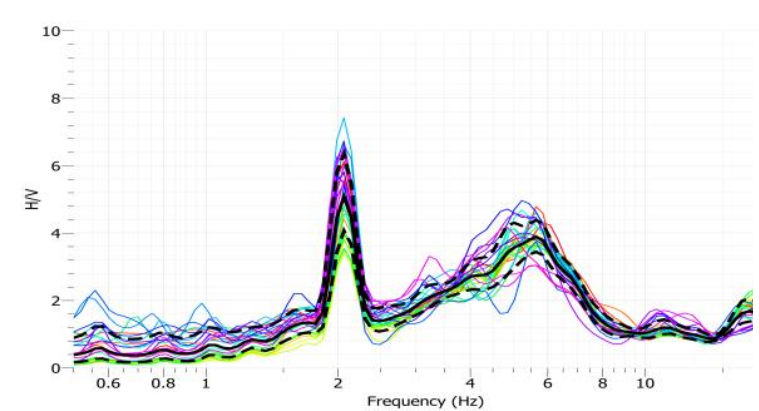

1

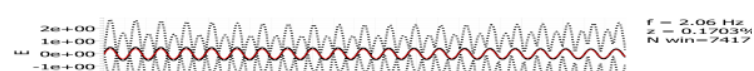

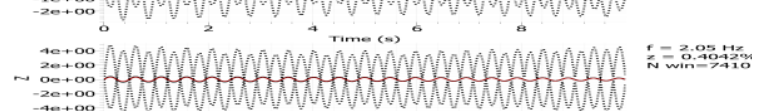
-

3

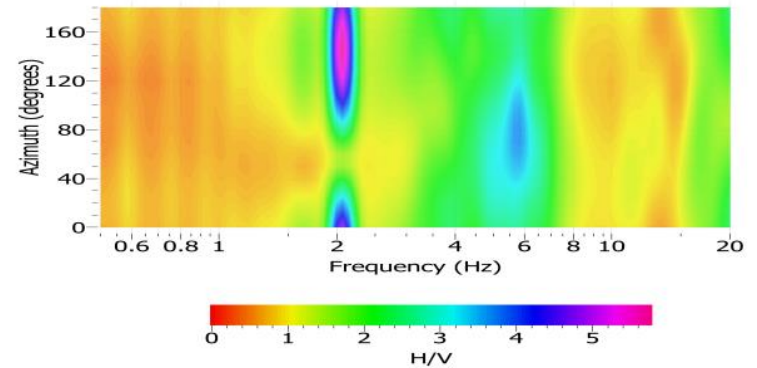

2

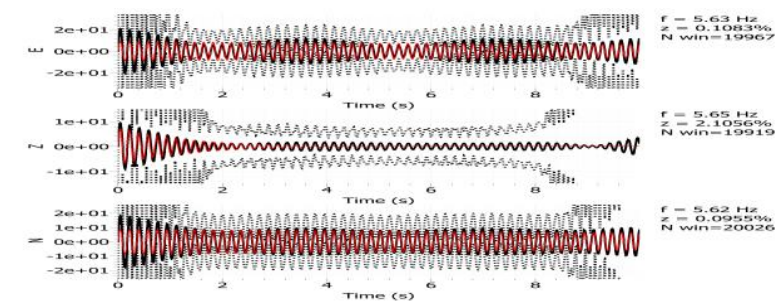

4

Fig. 10 Panel 1 represents the H/V spectral ratio curve; panel 2 shows the H/V rotation with azimuth degrees and panels 3 and 4 illustrate the damping test for the peak amplitude at frequencies $2.06 \mathrm{~Hz}$ and $5.63 \mathrm{~Hz}$. 